\title{
Exciting Developments in Agriculture and Renewable Energy
}

\author{
Brian Kirke* \\ Adjunct Senior Research Fellow, Sustainable Energy, University of South Australia
}

*Corresponding author: Brian Kirke, Department of Agricultural, Adjunct Senior Research Fellow, Sustainable Energy, University of South Australia.

Received Date: March 30, 2020

Published Date: April 17, 2020

\section{Mini Review}

This review summarizes three developments which could play a crucial role in reducing climate change effects.

The first is in agriculture. Farmer and author Charles Massey states that his book "Call of the Reed Warbler" is about the future survival of Earth and humanity. After decades of farming, following the advice of conventional agronomists and watching the fertility and productivity of his land steadily declining, he came to the view that "modern industrial agriculture and humanity's ongoing burning of stored fossil fuels is destroying Earth's life-sustaining systems, poisoning the foods we live on and divorcing us from a natural world we co-evolved with. While consuming more resources than Earth's systems can replenish, we are hurtling towards multiple calamities."

Many people would agree with this view, but unlike those who get stuck on the gloom and doom, Massey has studied ways to address the root causes of these impending disasters using new regenerative agriculture and landscape management.

In Zimbabwe, Allan Savory observed that de-stocking country did not halt desertification. Looking for reasons, he reasoned that grasslands evolved with large herds of grazing animals which stayed bunched up for protection from predators, constantly moving on to fresh grazing land, leaving the remaining vegetation trampled flat. This provided ground cover, moderating temperatures and delaying runoff, maximizing infiltration, providing mulch, while the dung and urine provided fertilizer so new vegetation had ideal conditions when the rain came. He tried mimicking this herd behaviour with cattle, grazing small areas intensively for a short period then moving the herd on and allowing plenty of time for the intensively grazed areas to recover. This approach was spectacularly successful. The land recovered remarkably quickly, fertility and productivity increased rapidly, and Savory's so-called "holistic planned grazing system," described by Massey as "one of the greatest forward leaps in agriculture since domestication 10,000 years ago," is now being practiced on over 15 million Hectares of grazing land on five continents.

By maintaining vegetation cover and reducing runoff, droughts and floods are reduced, soil carbon increases while photosynthesis and removal of $\mathrm{CO}_{2}$ from the atmosphere is maximized, thereby combating climate change. Savory quotes studies that claim that if his methods are practiced on half of the world's grasslands, $\mathrm{CO}_{2}$ levels would return to pre-industrial levels. There are several YouTube videos in which he explains his findings with great clarity, such as https://www.ted.com/talks/ allan_savory_how_to_fight_desertification_and_reverse_climate_ change?language $=\mathrm{en} \# \mathrm{t}-577104$.

To maintain ground cover while growing grain crops, Wes Jackson in Kansas is working on perennial grain species, and others are experimenting with sowing annuals into pasture.

According to the Wentworth Group of Concerned Scientists, an independent group of Australian scientists, economists and business people with interests in the conservation of Australia's land, water and marine resources, "A 15\% increase in the world's terrestrial carbon stock would remove the equivalent of all the carbon pollution emitted from fossil fuels since the beginning of the industrial revolution."

Massey cites examples of the benefits of holistic planned grazing. In one, a property ran 8000 dry sheep equivalents before 
changing to the new methods, and by 2009 , at the end of the "millennium drought," they were running 20,000 and increasing. Neighboring farmers had destocked and their dams were dry, while his were at least $2 / 3$ full.

Globally the area used for grazing is more than double that for arable and permanent crops. Animals contribute $30 \%$ of protein in human diets. Grasslands cover $40 \%$ of the planet excluding Antarctica and Greenland.

While Savory's methods are being adopted on land, another remarkable revolution is occurring in the ocean. In his book "Eat like a Fish," fisherman turned seaweed farmer Bren Smith describes his journey from fisherman to restorative ocean farmer when depletion of ocean fish stocks destroyed the ocean fishing industry. He found that he could make a good living by farming seaweed and shellfish in $8 \mathrm{Ha}$ of shallow seawater, requiring only a small boat and a series of lines (ropes) with anchors and floats, with no land, fresh water or fertilizer inputs, the nutrients in the water providing all the necessary nutrients, while the seaweed and shellfish absorb the nutrients which contaminate many coastal waters.

Quoting various sources, Smith asserts that "land-based agriculture already uses $70 \%$ of the world's freshwater resources and $90 \%$ of world fish stocks are already "maxed out" under the stress of overfishing and climate change .... Besides human food, seaweed can also provide fertilizers, animal feeds, even zero-input biofuels. Seaweeds like kelp grow faster and absorb more $\mathrm{CO}_{2}$ than land plants. Ocean farms equivalent to $5 \%$ of US territorial waters could create 50 million direct jobs, and a network of farms the size of Washington State $\left(184,827 \mathrm{~km}^{2}\right)$ could supply enough protein for every person living today, and farming $9 \%$ of the world's oceans could generate enough biofuel to replace all current fossilfuel energy. A non-profit company, GreenWave (https://www. greenwave.org/) has now been set up to train ocean farmers.
While people like Savory, Massey and Smith are pioneering exciting ways to restore the earth's fertility, combat climate change and feed the earth's population, exciting developments are also occurring in the field of renewable energy. Articles in the Australian Smart Energy Council's publication (www.smartennergy.org.au) argue that Australia's wind and solar resources are so plentiful that the country should aim to generate not just $100 \%$ of the country's domestic energy requirements, but $200 \%$ or even $500 \%$, the surplus for export to neighbouring countries, either by subsea power cables like the existing $300 \mathrm{~km}$ Basslink cable between Tasmania and the Australian mainland, and/or by generating hydrogen to be shipped in the same way as natural gas is now shipped, or in other more compact forms. The same could be done to supply Europe from North Africa and other industrialised areas from sunny and windy areas. And these proposals, although visionary, are not coming from the lunatic fringe, but from credible scientists and business leaders.

A generation ago we could not have foreseen the exponential growth of the wind industry, nor the drop in the cost of photovoltaics, nor the development of high energy density batteries that will give heavy trucks ranges of $1000 \mathrm{~km}$ (https://ultra.news/s-e/36643/ ashok-leyland-bets-israel-based-companys-aluminum-air-batteryelectric-commercial-vehicles/), and enable the development of emission-free electric aircraft https://www.telegraph.co.uk/ technology/2019/06/21/worlds-first-electric-plane-can-travel650-miles-battery-power/? And who can say what we might see in another generation?

\section{Acknowledgement}

None.

\section{Conflict of Interest}

No conflict of interest. 